\title{
1. Some Reflections on Anthropological Research in a Colonial Regime
}

\author{
Michael Allen
}

When I first began research in Nduindui district in west Aoba (subsequently renamed Ambae) in November 1958, not only was it well and truly prior to independence, but very few had even begun to seriously contemplate that they might live to see such a day. In other words, there was a feeling that though independence would most probably occur one day, it was still a long way off, maybe half-a-century or more away. If we had known that it would be a reality in a mere 22 years we would without doubt have been astonished.

It might help if I begin my story with a brief outline of just what set of circumstances led to my arrival in Port Vila on that, for me, highly auspicious day, 30 October 1958. And I still well remember when I stepped ashore from the Messageries Maritime mini-liner the Polynesie the truly astonishing sight of Keith Woodward (Assistant Secretary for District Affairs, British Residency) clad in resplendent and glittering white colonial gear, waiting to formally greet me with that intense yet slightly lost look that his already failing eyesight conveyed.

Just one year earlier I had completed an MA Honours Qualifying course in anthropology at Sydney University (SU) and for my fourth year's honours thesis I had carried out a library-based comparative study of male cults and initiations throughout Melanesia (Allen 1967). Of all the early ethnographic material that I had then saturated myself in none fascinated me more than the work of Robert Henry Codrington (1891), William Halse Rivers Rivers (1914), Arthur Bernard Deacon (1934) and John Willoughby Layard (1942), most particularly on both the public-graded societies and the secret societies of the northern New Hebrides. Hence, when I was offered a four-year postgraduate scholarship by the Australian National University (ANU) I expressed a strong preference to locate my $\mathrm{PhD}$ research in one of the less-studied communities in the northern district. But, by mere coincidence, at much the same time that I was offered my scholarship, the ANU had received a letter from the Colonial Social Science Research Council (CSSRC) in London, at that time the principal source of social science research funding in the UK, asking whether the ANU knew of a suitable anthropologist who might be interested in making a study of the social structure of Aoba Island (Comfort to Freeman). As I subsequently 
discovered, the applicant for the funding of such a project was John Rennie, the then British Resident Commissioner in the New Hebrides. Rennie had seemingly been motivated by two factors - first, he had studied anthropology at Oxford University and as a result strongly believed that colonial administrations would benefit greatly should its officers acquaint themselves with the results of good fieldwork-based anthropological research. Second, he chose Aoba for a number of reasons that I think are worth recording. Let me quote directly from Rennie's application to the CSSRC for funding:

I should like to see a social anthropologist undertake a study of social structure on the island of Aoba. I tentatively suggest that the study should have particular reference to the bases of social cooperation in this society, which has evolved in a climate of laisser-faire [sic] under the influence of uncontrolled pressures from missions, traders and war and ineffective administration by the Government.

In making my recommendation I have not lost sight of the survey made by Professor Elkin in Social Anthropology in Melanesia [Elkin 1953]. The project falls into one of his priority categories, a study of a disorganised community, but I prefer Aoba to the areas he lists and am fortified in this opinion by the knowledge that Monsieur Jean Guiart, the anthropologist who has the closest recent acquaintance with the New Hebrides, independently assigned the highest priority to a study of Aoba. (Rennie to Comfort).

John Barnes, who had supervised my fourth-year thesis at Sydney University (SU) and had subsequently been appointed to the chair of anthropology at the ANU, immediately suggested to me that in view of my preference to work in the northern New Hebrides he would be prepared to recommend me to the CSSRC. So, when I stepped ashore in Port Vila, I knew that I had, as it were, two sponsors with perhaps not entirely identical expectations as to the final outcome of my research. As regards the financial arrangements, my understanding was that the CSSRC would fully fund two years of fieldwork on Aoba with the ANU funding the time spent in Canberra analysing my material and the writing-up of my thesis. I do not, however, remember experiencing any undue anxiety regarding this arrangement, mainly because first Woodward and then Rennie soon assured me that they had no specific expectations other than the hope that I would eventually come up with a thesis that would satisfy my intellectual mentors and examiners. Rennie, however, seemed pleased enough when I promised him that I would make carbon copies of all of my reports to my academic supervisors and send them to him. For my part, the arrangement worked very well, indeed quite often I found Rennie's comments and observations at least as insightful and helpful as those that came from Canberra, and certainly a good deal more prompt. 


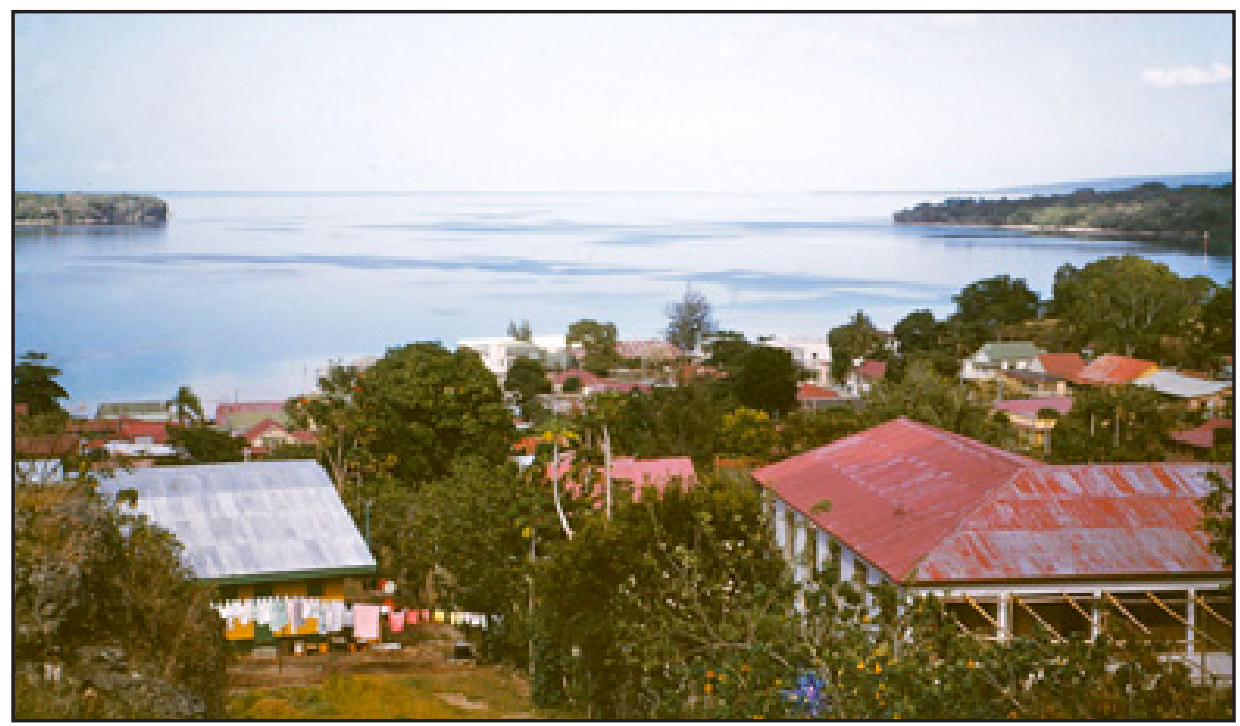

Figure 1.1. Port Vila, October 1958

(Michael Allen, photographer)

Before I finally managed to disentangle myself from the pleasures of Port Vila, Rennie elaborated a little more on what especially intrigued him about Aoba, most especially the Church of Christ-dominated Nduindui area of the western end of the island. What little he knew of this area, mainly from the occasional brief report from the northern district British Agent based in Luganville, was that the Nduindui people, far from being disorganised, took much pride in the fact that they could look after their own affairs, including the settlement of internal disputes and conflict, with the minimum of either interference or help from the colonial authorities. Indeed, the evidence was clear that they were inclined to resent any kind of outside interference within the district. In like manner, they regarded their resident white missionaries primarily as temporary professional helpers skilled in such matters as education and health. The actual running of the local church was firmly in the hands of the indigenous church elders.

Rennie was clearly of the opinion that if my research findings could document and analyse the means whereby the Nduindui successfully ran their own affairs then the British administration might indeed learn something that would enable them to facilitate similar developments elsewhere in the New Hebrides. As I subsequently discovered, the British Administration was at this time particularly keen to establish government-sponsored local councils on as many islands as possible. Prior to leaving Canberra, Barnes strongly recommended that on my arrival in Port Vila I should endeavour to meet Jean Guiart and hopefully get some useful advice as to how to successfully carry out fieldwork in the New 
Hebrides. Since I had previously received no fieldwork training or even casual advice at either SU or at the ANU, other than some hasty instruction in John Barnes's useful method for recording genealogies, this seemed like a good idea. When I asked Woodward if this were possible he informed me that Guiart was most probably somewhere in North Efate carrying out research on chiefly titles and that he, Woodward, would straightaway drive me up there and seek him out. But when we arrived at Paonangisu village we were told that the good professor had left on the previous day for the nearby island of Pele. An hour later I set out with a guide on a small outrigger canoe but on arrival at a coastal village we were told that Guiart had left that morning for a village on the other side of the island. This went on for two more days until I eventually caught up with him in Mangorango Village on Emau Island. He was sitting under a tree in the middle of the village surrounded by some of the older men.

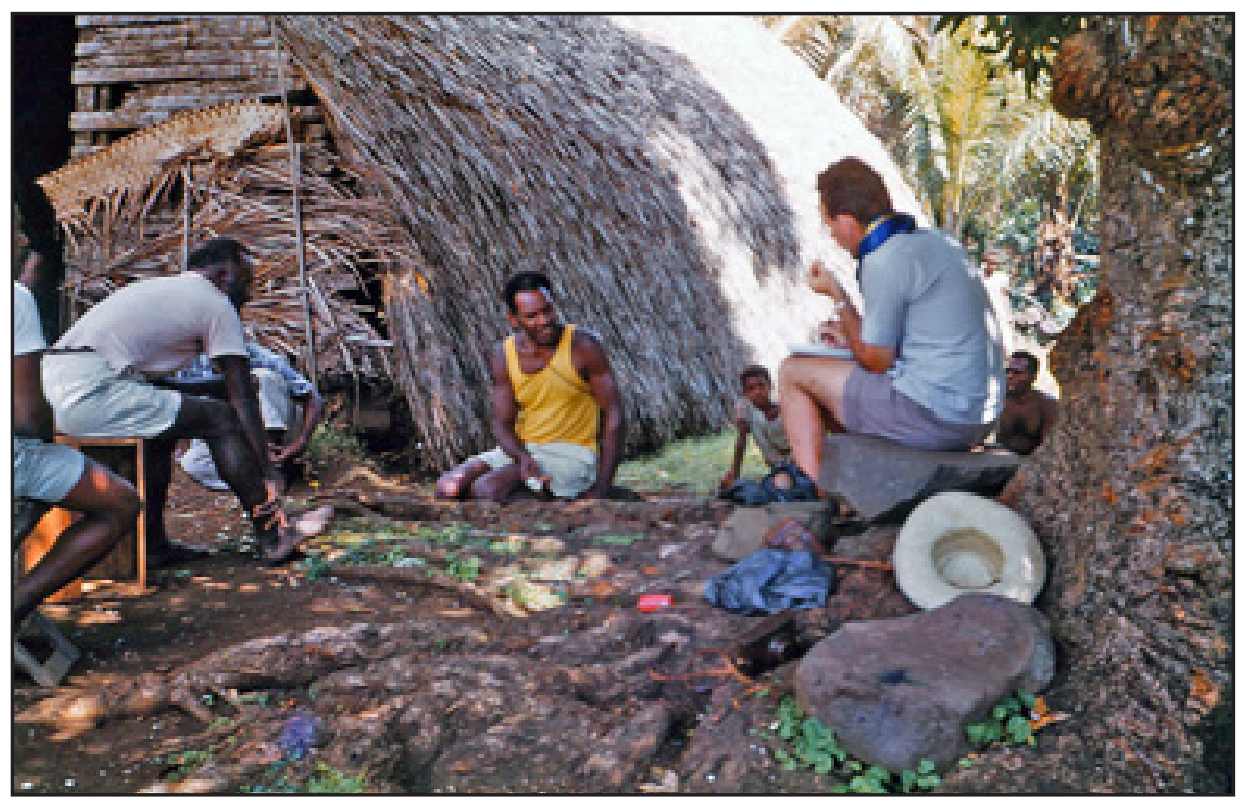

Figure 1.2. Jean Guiart at work in Mangarongo village, Emau, November 1958

(Michael Allen, photographer)

He immediately welcomed me, and when I told him that I hoped to get some fieldwork tips from him he generously invited me to sit and observe; which I duly did. For the next few hours he recorded the names of various titles and kinship terms, then closed his notebook and announced that it was time for us to proceed to the next village where he would record similar information. He added that in his opinion one or two days was the maximum time that one could expect a small Melanesian village to put up with the presence of a foreign anthropologist. Furthermore, it was, he asserted, good for one's health to spend most afternoons walking from one village to the next. Needless to say, 
this information seriously alarmed me, for if there was one thing I had learnt from my professors it was that good fieldwork depended on long residence, preferably from one to two years, in one's chosen community! Jean also strongly recommended that I should endeavour to record my information in my notebooks in such a manner that it could be prepared for publication with the minimum of additional work. This also astonished me!

But let me turn now to the other and more important side of the collaboration equation; that between myself as anthropologist and the Nduindui people. When I first arrived in the district, collaboration of any kind seemed, for the best part of the first two months, a remote and impossible dream. I soon found that the Church of Christ district council was indeed a powerful organisation dominated by a formidable elder by the name of Abel Bani. After my first meeting with Abel and my no doubt quite feeble attempt to explain that I would like to live in a village for a year or more in order to study and record as much as I could of their way of life, their stories, their knowledge of traditional custom as well their contemporary life style, Abel promptly informed me that they knew nothing whatsoever of kastom and hence I would be well advised to instead carry out my investigations in east Aoba, where kastom was still strong. Here, he said, with a somewhat severe expression on his dauntingly strong face, we follow the Christian way and regard kastom as the way of darkness. Nevertheless, he did agree to inform the Council of my desire and would in due course let me know their decision. At that point I began to fear that indeed Guiart's advice regarding the impossibility of prolonged residence in a small community was all too true.

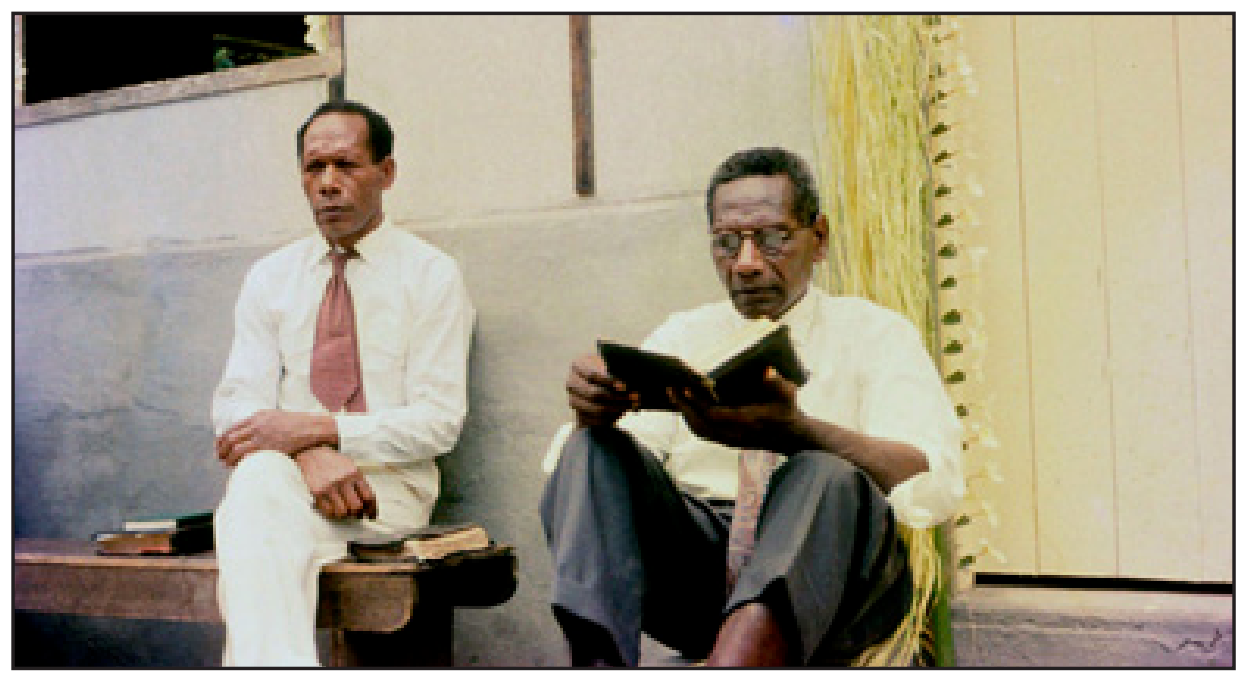

Figure 1.3. Isaac Vira (Navuti Elder) and Abel Bani outside Nduindui Church, November 1960

(Michael Allen, photographer) 
For the next month, while living with the piratical-looking yet kindly French trader Paul Leroux and his Tahitian wife, I paraded myself daily throughout Nduindui, stopping to talk with anyone prepared to listen and endlessly trying to explain what anthropology was and especially my desire to live in a village, and whilst there to attempt to learn the Nduindui language and to record as much as I could of both past and contemporary culture. Though many seemed friendly enough and even expressed some interest in my proposed work, they all confirmed Abel's opinion that everything depended on the Council's decision.

Three weeks later I was told by Abel that the Council had decided that they would prefer me to leave, but should any individual village invite me to live with them then they would have no objection. And sure enough, the following day Isaac Vira and Solomon Gamali, two good friends that I had recently made in Navuti village, informed me that the village council had decided to invite me to stay and that they would provide me with a small one-roomed hut to live in. They also told me that the principal reason for Abel's reluctance to welcome me was his fear that I might bring trouble to the district, as had frequently been the case in the past both on Aoba and on neighbouring islands, when whites were allowed to come and live in their midst, mostly as either traders or missionaries. My friends felt that Abel, and many other senior members of the district council, because they could not really understand what anthropology was about or what possible benefit it might bring to them, feared that I must really have other motives, above all that I might seek to acquire land or introduce yet another Christian sect. I even heard it said that some feared that if I fell ill or some other misadventure befell me then might not the Irish government send a gunboat to wreak vengeance, as had often enough occurred in the past when mishaps befell whitemen!

Needless to say I was transported into seventh heaven when a few days later I moved from Leroux's fortress-like trading post to my hut in the centre of Navuti and before long had begun language lessons and had recorded my first few genealogies. Though I did not use the word then, on looking back I can now say that I had begun to enjoy true collaboration. As the months went by a small number of men in Navuti and in surrounding villages became not just informants and friends but enthusiastic collaborators in the task of collecting whatever kind of information I was then interested in. To begin with it was mostly genealogies but it soon extended to using tape recorders to record songs, stories and myths. Foremost amongst those early collaborators in the anthropological enterprise were two who subsequently became amongst the first fieldworkers to work for the Cultural Centre, one of whom is still active today and has already made his valuable contribution to this conference-I refer of course to James Ngwero (also Gwero in this volume, see Ch. 5) of Nambangahage Village. I still remember very vividly when James came to me one day during that first spell of fieldwork 
and told me that he had written down a number of stories about the culture heroes Takaro and Mwerambuto that he had obtained from a knowledgeable old man in east Aoba called Harry Mala. I still hold those twenty or so beautifully handwritten pages of some five or six such stories that James very generously gave to me. Another early recruit as a Cultural Centre fieldworker was Emmanuel Vira Lalau. I have recorded many hours of Emmanuel singing traditional songs in that beautiful voice of his.

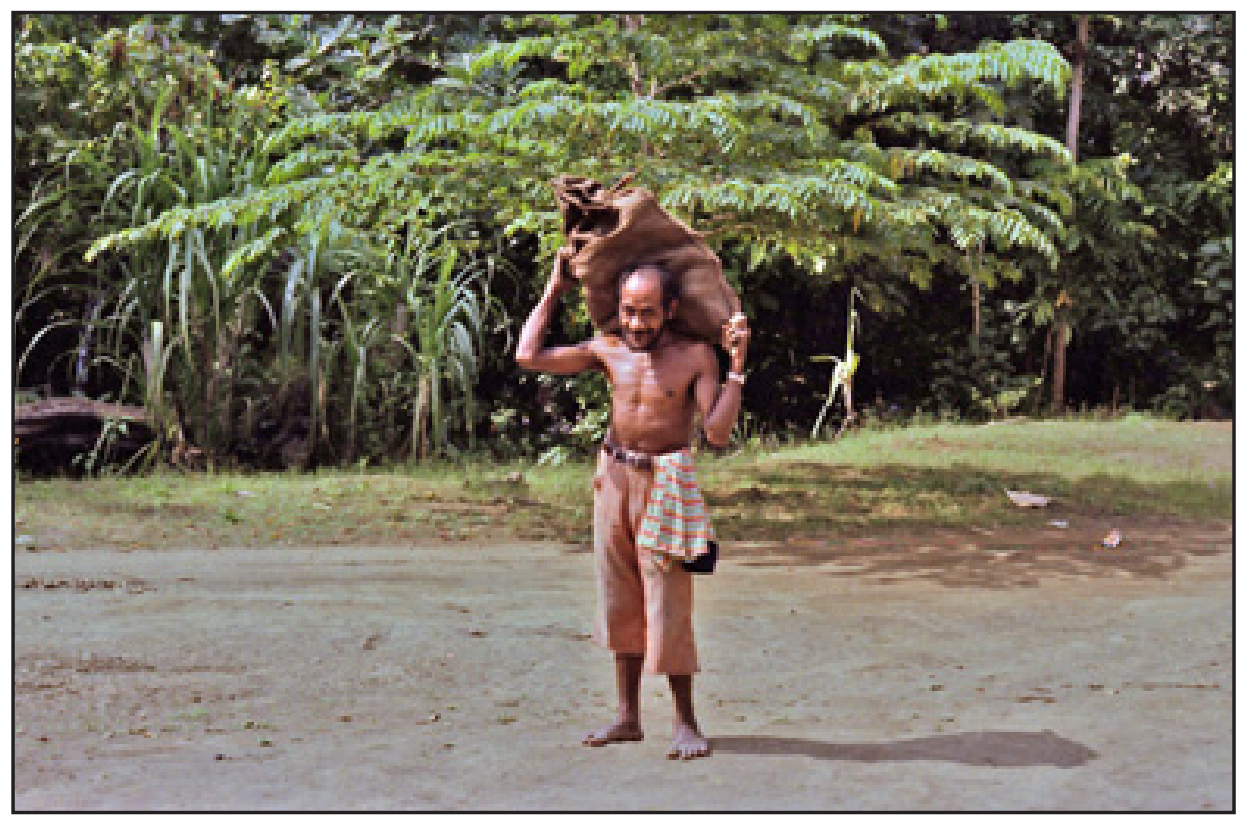

Figure 1.4. Emmanuel Vira Lalau with a bag of kava roots, Lovanualigoutu, May 1980

(Michael Allen, photographer)

There were, however, incidents that, though not of a lasting kind, nevertheless momentarily threatened this on-going happy collaboration. Perhaps the most notable occurred during my second period of fieldwork. By then I had begun to envy the two local missionaries, Ron Maclean of the Church of Christ and Paul Grant of the Apostolic Church in nearby Walaha, both of whom owned light though powerful motorbikes that whisked them with ease over rough tracks to the most remote villages whilst I spent many hours lugging notebook, camera and sometimes tape recorder over the same routes. One day I wrote to Woodward and asked if by any chance the British Administration in Vila happened to have an unused motor bike. To my surprise they evidently had and a week or two later it arrived via the Burns Philp trading vessel at Nduindui anchorage. So down I eagerly rushed to receive it. But my heart sank when I saw that in place of the usual uninformative number plate it had a large plate clearly labelling it 
as 'BR 3' (British Residency 3). After almost 18 months of carefully distancing myself from the British Administration as much as I reasonably could, here I was driving up to Navuti on a British Residency bike! But by then it seemed that my credentials were well enough established to laugh this one off and soon every young man in Navuti was begging to have a go on the bike.

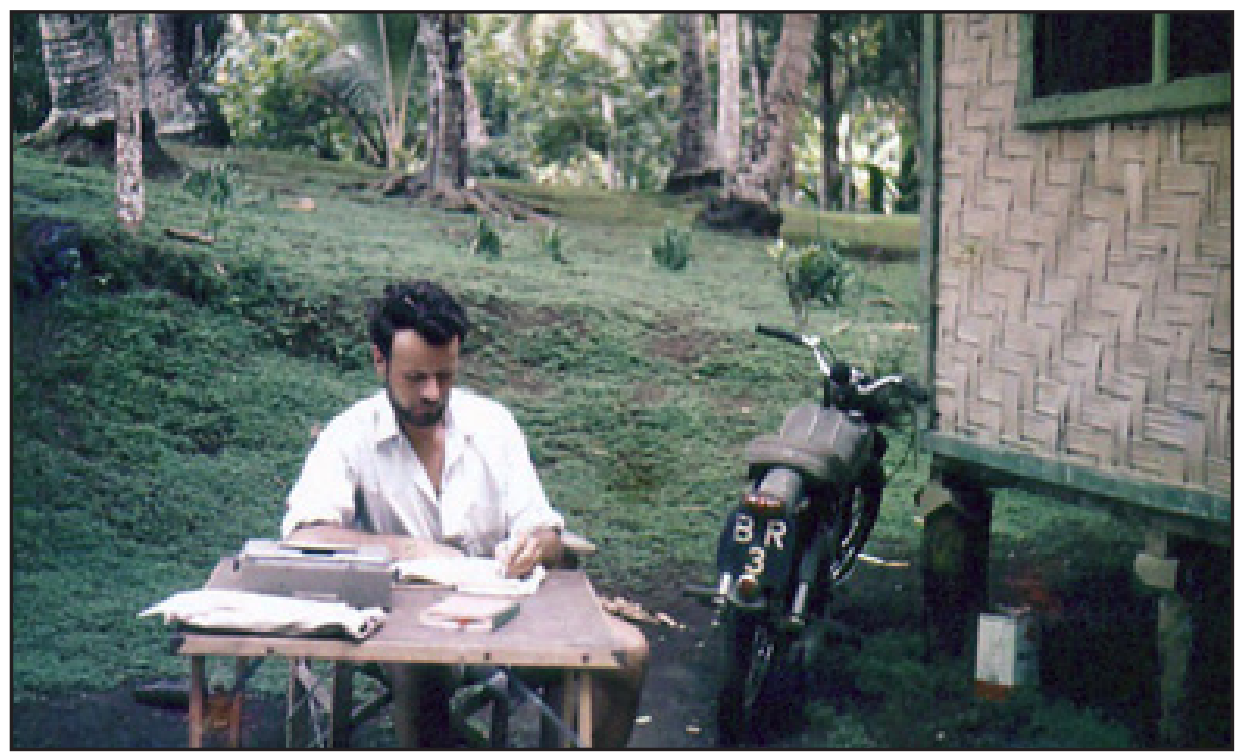

Figure 1.5. Michael outside his hut in Navuti Village with the BR 3 bike, September 1960

(photograph taken by Joel Tari of Navuti Village)

But, perhaps most important of all, what in retrospect I most value as a product of my collaboration both with the British Administration and with the Nduindui people was that as part of my promise to Rennie, though by then he had left to become the Governor of Mauritius, I had indeed submitted to his successor Colin Allan copies not only of all my reports to the ANU but also of various seminar papers that I had read to my anthropological colleagues. These remained for some years in the offices of the British Administration in Vila until one day Caroline Leaney, by then the ex-wife of a British District Agent, came across them, edited them and put them put together in 1969 as a kind of soft-back publication (Allen 1969). Very kindly, she not only sent me some 20 copies, of which I now possess only one, but arranged for about a dozen more to be sent to individuals whom I nominated in various villages throughout West Aoba. As I know from subsequent visits to Nduindui, the last being in 2003, most if not all of these are still held by families in the same villages. Needless to say this gives me considerable pleasure to contemplate - indeed far more so than the copies of my much more arid $\mathrm{PhD}$ thesis that can be found languishing in a number of university libraries. 


\section{References}

Allen, M.R., 1967. Male Cults and Secret Initiations in Melanesia. Melbourne, VIC: Melbourne University Press.

Allen, M.R., 1969. Report of Aoba: Incidental Papers on Nduindui District, Aoba Island, ed. C. Leaney. Vila: British Residency (Mineographed).

Codrington, R.H., 1964. The Melanesians: Studies in their Anthropology and Folklore. Oxford: Clarendon Press.

Comfort to Freeman, 1957. File RES.88/47/01, Colonial Office, October.

Deacon, A. Bernard, 1934. Malekula: A Vanishing People in the New Hebrides. London: George Routledge and Sons.

Elkin, A.P., 1953. Social Anthropology in Melanesia: A Review of Research. London: Oxford University Press

Layard, J., 1942. Stone Men of Malekula. London: Chatto and Windus.

Rennie to Comfort, 1957. File RES.88/47/01, Colonial Office, October.

Rivers, W.H.R., 1968 [1914]. The History of Melanesian Society. 2 volumes. The Netherlands: Anthropological Publications, Oosterhout N.B. 